Portland State University

PDXScholar

$11-5-1997$

\title{
Teaching Culture in German: Standards, Perspectives, Resources
}

Alexander Lukanich

Portland State University

Follow this and additional works at: https://pdxscholar.library.pdx.edu/open_access_etds

Part of the German Language and Literature Commons Let us know how access to this document benefits you.

\section{Recommended Citation}

Lukanich, Alexander, "Teaching Culture in German: Standards, Perspectives, Resources" (1997).

Dissertations and Theses. Paper 5322.

https://doi.org/10.15760/etd.7195

This Thesis is brought to you for free and open access. It has been accepted for inclusion in Dissertations and Theses by an authorized administrator of PDXScholar. Please contact us if we can make this document more accessible: pdxscholar@pdx.edu. 


\section{THESIS APPROVAL}

The abstract and thesis of Alexander Lukanich for the Master of Arts in German were presented November 5, 1997, and accepted by the thesis committee and the department.

COMMITTEE APPROVALS:

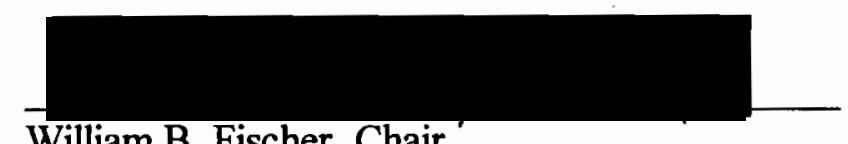

William B. Fischer, Chair

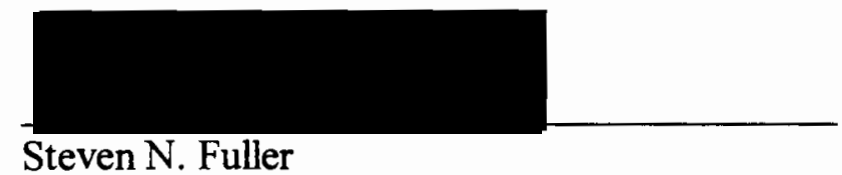

DEPARTMENT APPROVAL:

Louis J. Elteto, Chair

Department of Foreign Languages and

Literatures

ACCEPTED FOR PORTLAND STATE UNIVERSITY BY THE LIBRARY

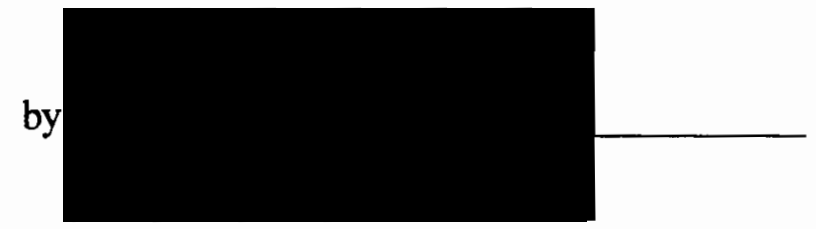
on

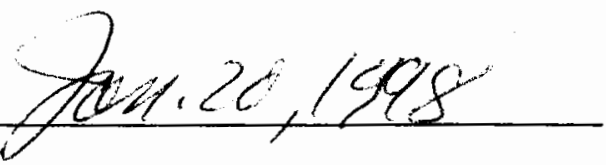




\begin{abstract}
An abstract of the thesis of Alexander Lukanich for the Master of Arts in German presented November 5, 1997.
\end{abstract}

Title: Teaching Culture in German: Standards, Perspectives, Resources.

Americans face a serious challenge today: the need to become more competent in the languages and cultures of the rest of the world. Technology has brought nations closer together. International trade has grown to the creation of a global economy. Americans have greater contact with the cultures of other nations and encounter growing diversity within their own borders. In spite of these demands, Americans remain largely unable to speak other languages, or understand other cultures.

Cultural instruction must play an increasingly important role in education. Foreign language teachers must teach culture as a regular and prominent part of their foreign language courses. Students must learn about culture; teachers must evaluate them on their grasp of it. For all its importance, a common understanding of what culture means and how it should be taught are lacking. For foreign language teachers, culture must encompass all the values, beliefs, manners, behaviors, attitudes, technologies and forms of language common to a given group of people. 
Teachers must teach increasingly diverse students to ever-rising standards while making use of new and traditional methods and resources. With proficiency as a guiding principle, teachers must establish a student-centered classroom with emphasis on hands-on learning. Teachers must create an enriched learning environment which incorporates authentic materials and new technologies. Using a thematic approach, and viewing culture as a process rather than a set of static facts, teachers must fully integrate the teaching of language and culture such that the two become inseparable.

This thesis discusses critical issues in teaching culture as reflected in professional journals, focusing on teaching culture in the German classroom. The Introduction documents the need for increased language and culture study. This establishes the context in which cultural instruction will occur. Teaching Culture first constructs a working definition of culture and ethnocentricity. The discussion then continues to standards, goals, and expectations; perspectives on teaching culture, including a working model of cultural instruction and application of proficiency principles to cultural instruction; and an examination of new and traditional resources for the teaching of culture. The Conclusions stress the importance of adequate teacher training programs. 
TEACHING CULTURE IN GERMAN:

STANDARDS, PERSPECTIVES, RESOURCES

by

\section{ALEXANDER LUKANICH}

A thesis submitted in partial fufillment of the requirements for the degree of

\section{MASTER OF ARTS}

in

GERMAN

Portland State University

1997 


\section{TABLE OF CONTENTS}

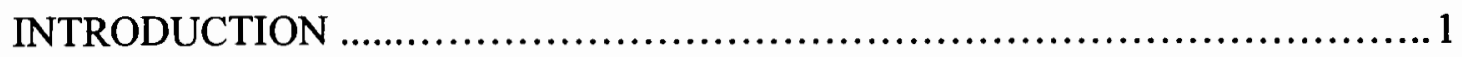

TEACHING CULTURE........................................................ 8

A Definition of Culture................................................. 8

Rising Standards..................................................... 13

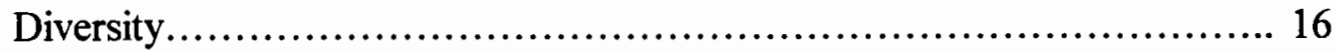

New Perspectives................................................... 21

New and Traditional Resources.......................................... 30

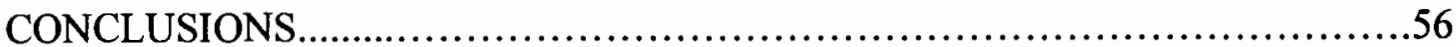

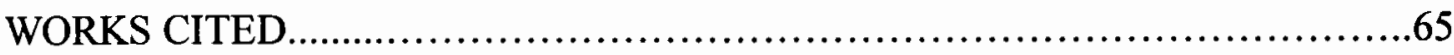




\section{INTRODUCTION}

Americans are facing a serious challenge on the eve of the $21^{\text {st }}$ century: the need to become more competent in the languages and cultures of the rest of the world. In 1991, U.S. Representative Leon E. Panetta (California) wrote that we are "faced with global complexities and challenges never before encountered in the history of mankind" (127). Technology has brought nations closer together. International trade has grown to the creation of a global economy. Americans have greater contact with the cultures of other nations and encounter growing diversity within their own borders. Panetta also cited the growing interdependence of the world's nations as a pivotal point: "We know that nations will continue to become more interdependent; that our fragile world will face crises in resources, the environment, and overcrowding; and that technological advances will contribute to even greater global shrinkage" (127). This interdependence brings with it the need to communicate, which in turn necessitates greater cultural understanding. As Cadd states: "People from diverse fields have made the claim that language study may help provide students with the mindset necessary to function in such a world" (143-4). 
In spite of these demands, Americans remain largely unable to speak other languages, or understand other cultures. Panetta wrote that, while some progress has been made since the President's Commission on Foreign Languages and International Studies described the situation as "scandalous" in 1979, it is nonetheless now "merely appalling" (128-9):

Thirty-five states report current or projected foreign language teacher shortages;

Fewer than twenty percent of our elementary schools offer any form of language instruction;

Fewer than ten percent of our high school graduates have taken four years of a foreign language;

Fewer than one percent of our students study Japanese, Chinese, Arabic or Russian, the languages of three-fourths of the world's population; It remains possible to acquire a post-graduate degree in the United States without ever encountering a foreign language, geography or world history. . . (129)

China, a developing country with a $9 \%$ annual economic growth rate (International Monetary Fund 26), provides English as a mandatory course for all students beginning in the fourth grade and continuing until the second year of college. In contrast, American schools and colleges continue to marginalize foreign languages in the curriculum as subjects with fewer or no requirements for graduation. Nollendorfs 
speaks of disciplinary and institutional marginalization" at the university level (1).

Oregon's House Bill 3565, Section 3, mandates a high degree of mastery in science and mathematics, but only a background knowledge in social studies, foreign languages, the humanities, and collective fine arts. Students who do learn to speak a foreign language receive primarily linguistic instruction (2). Most study a language for only two years: “29.6\% of all German students discontinue after level one, $71.2 \%$ by the end of the second year, and $86.4 \%$ after three years" (Minert 174). It is clear that serious inquiry must be made into the multiple factors behind this phenomenon, yet

1 Few studies have been conducted concerning the German enrollment question in the last 20 years.

2 Only one study is available on this topic in a geographic area larger than a county.

3 Few studies have investigated this phenomenon from the perspective of the students. (Minert 174)

With such modest preparation, students' understanding of the foreign culture cannot achieve the depth necessary to make their efforts at communication meaningful and appropriate beyond the simplest level.

Educators must provide increasing opportunities for language instruction as the need for such skills grows. Instruction must extend beyond two years to allow development of greater fluency. Rather than being relegated to the sidelines, culture 
must take its place alongside language skills as an integral and necessary element in foreign language education (Flewelling 140).

The federal government has responded to the challenge. Conley et al. remark that the "movement to develop national educational goals related to specific student knowledge and skills has been swift and unprecedented." Whereas historically "any hint of federal standard-setting has been greeted with suspicion and hostility" by the states, "federal influence ... has increased during the past thirty years." This influence has concerned itself primarily with the issue of equal access to education, "based on three important pieces of legislation, the Elementary and Secondary Education Act, ESEA, Title IX, and the Education for All Handicapped Citizens Act, P.L. 94-142" (19).

Conley et al. describe increased federal intervention after the 1983 release of the Nation at Risk report, which condemned the state of education in the U.S. The report provided the momentum for a critical analysis under the Bush Administration, resulting in six National Education Goals which "formed the basis of the America 2000 program . . . unveiled in April 1991". In essence, these goals called for raising American students to the top of the class: "By the year 2000, U.S. students will be first in the world in mathematics and science achievement." Conley et al. do not mention foreign language skills. The federal government also established the National Council on Education Standards and Testing (NCEST) and the National Education Goals Panel (NEGP) specifically to facilitate the establishment of national standards. 
Two additional agencies were slated for funding, the National Education Standards and Improvement Council (NESIC) and the National Skills Standards Board (NSSB) (qtd. in Conley et al. 20).

Various educational organizations initiated subject-specific studies, such as the National Council of Teachers of Mathematics (NCTM), for mathematics; and the National Research Council (NRC), for science. The American Council on the Teaching of Foreign Languages (ACTFL) and language-specific organizations such as the American Association of Teachers of German (AATG) have jointly launched a project called the National Standards in Foreign Language Education, which receives funding from the U.S. Department of Education (Conley et al. 23-5). The standards developed during this project are now complete (see Conclusions regarding teacher education, pages 58-61).

States have passed their own legislation aimed at improving the state of American education, such as Oregon's House Bill 3565, the "Oregon Educational Act," which calls for a new system based on proficiency, a system which places little emphasis on traditional letter grades but rather on student demonstration of competence (Conley et al. 5-7). As stated above, Oregon's new standards are higher for mathematics and science than foreign languages and the humanities (see page 3).

The much-needed focus on foreign languages and cultural instruction came from U. S. Representative Panetta, who urged the creation of the Globally Aware America Program (GAAP), which would "close the gap" by the year 2020 (129). To 
do this, it would provide for foreign language education at every level from $\mathrm{K}$ through 12; require foreign language, culture and literature studies for all students, including the demonstration of competence in a foreign language; call for the integrated use of foreign languages and "international knowledge" in higher education institutions; make language study available to areas such as law enforcement, social services and health care; encourage study of second language acquisition; provide periodic study abroad opportunities for teachers; generate a ten-fold increase in study abroad opportunities for students; place greater emphasis on languages such as Arabic, Chinese and Japanese; make use of new technologies such as the Internet to link our students with students in other countries; and provide assistance to businesses as they develop international ties (129-30).

Rising standards and availability of new resources correlate with new perspectives in how language and culture can be taught. Teachers must no longer view culture as a set of constant facts or slowly evolving statistics. Culture is a process which requires active learning if students are to grasp its complex, variable and everchanging nature. Any working model of cultural instruction must take into account learning outcomes, larger educational objectives, perspectives on proficiency, and ways of utilizing new and traditional resources.

Finally, a critical component of any discussion of the ways in which German teachers can approach the teaching of German culture must be the cultural context in which that instruction will occur. German teachers face an increasingly diverse student 
population in their classrooms. According to the 1980 census, "'one-quarter to onethird of all Americans will belong to racial or ethnic minority groups"' in the next century. Minorities will outnumber whites in California and other locations by the year 2000. In fact, demographic changes will be more significant than earlier projections indicated. The Population Reference Bureau indicates that over half of all Americans will belong to minority groups by 2080 . This diversity will not be restricted to certain regions, but will be widespread, "with virtually every corner of the nation drawing Asians and Hispanics from a range of different national backgrounds"', according to the 1990 census ( $q$ td. in Henderson 107). As Henderson states, "it is clear that diversity is going to be the issue for this decade and beyond, not just in parts of the country, but across the nation" (107).

The thesis which follows begins by establishing a working definition of culture and ethnocentrism, which must be overcome if meaningful cultural learning is to occur. It then discusses standards for cultural instruction, focusing on Oregon's guidelines for the Certificate of Initial Mastery, which students are to complete by the end of their sophomore year. The discussion includes exploring larger goals and objectives, and the need to involve all students in the learning process. Next, the thesis focuses on perspectives on teaching culture, providing a working model of the culture learning process and relating it to the proficiency principle. Finally, the thesis reviews the variety of resources which teachers can utilize in teaching culture. The conclusions which follow include recommendations for teacher training. 


\section{TEACHING CULTURE}

Culture is a complex word, rife with associations and connotations. Whether in everyday use or in the terminology of anthropologists, any clear consensus on its proper definition is lacking (Ryan 573). Nonetheless, as cultural instruction becomes increasingly important (Cadd 143-4), foreign language teachers must teach culture as a regular and prominent part of their foreign language courses. Students must learn about culture; teachers must evaluate them on their grasp of it. Specifically, foreign language teachers must increase their own understanding of culture, understand and implement rising standards. address the diversity of their students, seek new perspectives on teaching culture, and learn ways to utilize new and traditional resources.

\section{A Definition of Culture}

Anthropologists, sociologists, geographers, historians, philosophers, artists, linguists, and language teachers have distinct ways of seeking an understanding of culture. In addition, each student who wishes to learn about another culture will bring with him or her unique experiences, interests and needs. For all our similarities, human 
communities around the world possess considerable variation. Those who study and learn about them are at least as diverse. Nonetheless, a common definition of culture is necessary for those who will teach about culture. Hoopes and Pusch offer an allencompassing view:

Culture is the sum total of ways of living; including values, beliefs, esthetic standards, linguistic expression, patterns of thinking, behavioral norms, and styles of communication which a group of people has developed to assure its survival in a particular physical and human environment. (3)

Additionally, Hoopes and Pusch stress that culture is not static but ever-changing, "the response of a group of human beings to the valid and particular needs of its members." Culture therefore possesses an "inherent logic" and an "essential balance between positive and negative dimensions" (3). Since culture has multiple dimensions, the work of foreign language teachers in teaching culture will have many facets. A broad perspective on culture is therefore particularly valuable for foreign language teachers, who must attempt to recreate a foreign culture in their classrooms.

Such a broad definition of culture, however, is meaningless if teachers do not relate it to themselves. Teachers need a common understanding of culture so that they may teach it as part of a shared curriculum. For their definition of culture to be useful, teachers must apply it consciously and consistently in their work. Frank M. Grittner, editor of Foreign Language Annals, offered this view: "Someone once asked, 'How 
are wrist watches and the definition of culture identical?' And the answer was, 'No two read the same, and each of us believes our own"' (17). Similarly, views on teaching culture are as numerous as the teachers who teach culture (Ryan 572).

In spite of this, certain commonalties do exist. In earlier decades, foreign language teachers understood teaching culture as teaching literature. Language courses taught language skills as quickly as possible so that students would be able to access "great literary works" at the earliest opportunity. "It was through reading that students learned about the civilization associated with the language being studied. This type of culture is often referred to as 'capital C culture." Big C culture focuses on that side of culture which is reflected in the arts and in technology. Beginning in the 1960s, "small C culture" became an acceptable part of the curriculum. It focuses on "the study of a people's customs, manners, values and beliefs" (Flewelling 133-4). In both cases. teachers approached culture as a static collection of ideas or works of art: "a series of facts" (qtd. in Flewelling 135).

Today, teachers are more apt to view culture as a living process, an open-ended and ongoing pattern of development within a given society. Ryan cites these attitudes toward culture from teachers who participated in a two-year study in Mexico:

Culture is the daily life of a group of people.

Culture is transmitted from one generation to another.

Culture is lived and experienced. 
Culture is knowledge gained from reading.

Cultural institutions should be analyzed.

Culture means having a critical attitude toward the world. (576)

The traditional perspective on culture as something students learn about through reading continues alongside broader perspectives on culture as process.

Teachers in the study were generally aware that their own views on culture had changed over time:

It could be a traditional, old-fashioned form, let's say classical music, literature, painting. Everything that makes up a cultured person. I think as an adolescent I wanted to have culture.... But this is an aspect that I consider narrow now. Now I think that culture is all the manifestations or all the scientific and literary and technical products and customs of all types that exist in a country. It is a wider concept. (Ryan 576)

Professional literature supports this teacher's perspective that foreign language teachers should take on open view on culture. By considering a broader range of cultural artifacts as viable indicators of culture, teachers can utilize a broader range of materials for teaching culture, not just traditional literary works (Grittner 18).

Another participant in the study saw culture as possessing considerable diversity: 
I think that the culture of a country is a multiplicity of cultures. The way of knowing how to live and to see the reality of learning it and thinking about it and participating in it is not the same between a man and a woman even from the same country. It is not the same between an adult and a child, between a person who has studied and one who has not, between a peasant and a worker, between a bureaucrat and an intellectual. So, there are certain groups that share certain values, certain concepts, certain ways of understanding reality and participating in it. This makes up a mosaic ... that you could call microcultures. This interrelationship . . . for me is unpredictable, uncontrolledbecause it is always in perpetual movement, in perpetual change due to phenomena of action ... also an important question is creation, people who criticize their reality and change it. (Ryan 580)

This individual's perception of culture takes into account the diversity of culture, the differing perspectives on the same culture by different members of that culture, the notion that culture evolves, and individuals can help shape their cultural reality. As a whole, the views above form a very solid, if complex, working definition of culture.

If teachers are teaching students about culture, then it is the students' own ethnocentrism which teachers are working to overcome. Cadd cites Sumner's definition of ethnocentrism "as the belief that 'one's own group is the center of everything, and all others are scaled and rated with reference to it. Each group 
nourishes its own pride ... and looks with contempt on outsiders...." Cadd relates Adorno's ingroup-outgroup paradigm, where the ingroups display "hostile attitudes toward outgroups and have stereotyped positive images toward themselves." Hence, an ethnocentric student will distinguish between ingroups and outgroups, perceive himor herself as belonging to an ingroup, and view outgroup members in unfavorable stereotypes (qtd. in Cadd 145). The implication of this for the foreign language classroom is that the foreign language teacher will need to work with students to help them overcome their ethnocentrism. Students should learn to view the target culture as different, not necessarily better or worse and certainly not inherently worse, which is the hallmark of the ethnocentric viewpoint.

\section{$\underline{\text { Rising Standards }}$}

Second, foreign language teachers must reflect not only on a suitable working definition of culture, but also on rising standards which now expressly call for cultural learning with specific outcomes. A Canadian study focusing on French language and cultural instruction in Canada offers relevant insights. The National Core French Study, published in 1990, suggested these goals:

to help students understand and appreciate francophone culture; to prepare students for life in a bilingual, multicultural Canada; to broaden students' horizons; 
to help students gain a better understanding of their own culture;

to increase student interest in the French language;

to improve student skills in the French language;

to reduce ethnocentric attitudes toward the students' own culture. (qtd.

in Flewelling 134)

In the U.S., the National Standards in Foreign Language Education Project published its 1995 final report which included this philosophy:

'Communication is at the heart of the human experience. The United States must educate students who are linguistically and culturally equipped to communicate successfully in a pluralistic American society and abroad. ...' (qtd. in Fischer 76)

In Oregon, foreign language teachers are planning ways to prepare their secondary students to meet new standards as part of the Certificate of Initial Mastery (CIM) which students must earn by the end of their sophomore year. General CIM Common Curriculum Goals for culture require students to:

Comprehend and use appropriate verbal and nonverbal practices in common situations occurring within a second language culture; Compare and contrast cultural practices of the first and second language cultures. (Oregon DOE 49)

The specific level of skill which students must demonstrate on the ACTFL scale remains unclear. Oregon educators are considering basing CIM standards on the 
ACTFL Novice/High level. CIM cultural learning goals for this level are as follows:

Comprehend and use some common social conventions, social courtesies and nonverbal cues;

Compare and contrast common social conventions, courtesies and nonverbal cues. (Oregon DOE 49)

Such a demonstration of cultural awareness would correspond to appropriate language skills in the four skill areas: listening, speaking, reading, writing. Novice/High listening skills, according to CIM standards, call for comprehending "main ideas and details in statements and questions on everyday topics." Speaking skills entail use of "phrases, sentences and questions to express ideas and some details on a range of topics." Reading skills call for comprehending "main ideas and some supporting details from simple narratives and materials, such as menus, notes and schedules." Lastly, writing skills involve "writing or composing short messages, notes and simple guided paragraphs" (Oregon DOE 48-49). While these standards may appear vague, German teachers trained in proficiency principles will readily relate them to the ACTFL guidelines on which they were based and should arrive at a common conception of the skill level which the CIM standards require. Similarly, teachers trained to administer the ACTFL Oral Proficiency Interview (OPI) are able to deliver consistent evaluations based on their extensive training (Liskin-Gasparro 39). While not all Oregon foreign language teachers will receive such extensive training, ACTFL does offer a pared-down version of the OPI training course which would be adequate for high school teachers. 
Indeed, adequate professional literature exists to support Oregon's new standards and provide a detailed interpretation of their expectations.

\section{Diversity}

Third, all public school teachers must address the diversity of their students in their teaching of any subject (Henderson, Action 4). A draft statement of the AATG Committee for the Recruitment and Retention of Minorities in German calls for the AATG to affirm "the diversity of our citizenry and the wealth of a multicultural, multilingual society" (qtd. in Peters et al. 97). As editor of Die Unterrichtspraxis, a leading professional journal for the teaching of German, Peters cites an "urgent need to improve the record of minority participation in German at all levels and to underscore the value of a truly diverse German classroom-diverse in gender, age, ethnicity, sexual orientation, and physical ability" (Peters vii).

Likewise, the Student Task Force on Diversity at UC Davis believes "that all students, irrespective of sex, class or ethnicity, should be exposed to the benefits inherent in learning another language, particularly German.” The Task Force refutes any suggestion of cultural imperialism. They believe that language study is beneficial to all students. There is nothing incongruous about African-American students learning German, since the African-American community itself recognizes the importance of foreign language study. With European unification and economic cooperation increasing, German is an important language in the international marketplace, 
regardless of the color of the students who study it (O'Mahony 116). All students benefit from the study of foreign languages, and foreign language teachers must be able to handle the diversity of the students who appear in their classes.

The teaching assistants who participated in the Task Force were quick to recognize their own lack of experience in dealing with diverse students: "As white educators, we discovered how little we knew of the experiences and perceptions of students of color." The teaching assistants "began to ask how the way we teach affects the way students from different cultural backgrounds learn and how students of color perceive white faculty." Through a dialogue with students of color in their classes, the teaching assistants found that most minority students did not feel "devalued or segregated," but did feel the need for materials and curriculum to address the relevance of the subject to their lives: "These should include positive reference to people of color and avoid unnecessary stereotyping." Minority students were also interested in learning about career opportunities where they could use their German skills and were very interested in learning about current and recent events. In particular, they felt the "xenophobia and racial violence as manifested in the numerous outbreaks of neo-Nazi violence in Germany" were important to study. The Task Force subsequently conducted a study of the curriculum and materials at UC Davis "with respect to the portrayal of diversity in German society and culture" (qtd. in O'Mahony 118).

Karl F. Otto, Jr., of the University of Pennsylvania, researched materials for the teaching of German and found that "the target audience seems to be composed 
primarily of white (heterosexual) males. Although recent textbooks do include women, people of color are largely "invisible." He cites rising numbers of Asian students in German classrooms, yet other minority groups "are still underrepresented." Using U.S. Census Bureau projections, Otto warns that "non-white students are likely to register for our classes in ever-increasing numbers, as will female students although many German programs have already seen a substantial increase in female majors and graduate students." The curriculum and materials these students will encounter typically fails to include them, their perspectives and interests, as it does the perspectives and interests of white or male heterosexual students. Otto states that it would be very easy to prepare for this change in student demographics "by having available for them materials with which they can identify." He provides as examples the emphasis on Christmas and Easter in German textbooks, which Jewish students do not relate to with the same enthusiasm as their Christian peers. Similarly, not many "gay and lesbian students are overly enthusiastic when talking about dating and marriage, especially the 'marriage ads' most texts now have" since all textbooks are devoid of any ads "which are not clearly heterosexual in nature" (153).

It is not enough merely to print pictures of non-whites living in Germany, of which there is a growing number of Turks, Eastern and Southern Europeans. Such tokenism does not take into account the identities of the students it attempts to include. Research has demonstrated that different cultural groups can possess differing learning styles. Otto quotes Olguin: "We will not want to "teach students what a text says, but 
to teach them how to hear what it says to them"' (155). Consideration of cultural differences in learning styles must be a part of teachers' larger obligation to incorporate knowledge of differing learning styles and intelligences into their instructional program. As such, a student-centered classroom can truly become a learner-centered classroom. Drawing from German culture, Otto furnishes several themes or topics which could form the basis of cultural units in a German classroom. Where a specific form of diversity is not common in Germany, such as black citizens. Otto shows how other connections can be made. For example, jazz music, "which has its roots in the AfricanAmerican community of this country," is very popular in Germany. Black authors, such as James Baldwin, are well known to Germans. Likewise, sports are an international phenomenon and players from many countries compete on German soil (156). Such connections might appear loose, but they can make an enormous difference as a teacher demonstrates sensitivity and makes an effort to include all students in the classroom experience.

There is another facet to diversity which concerns the German teaching profession: teaching students with disabilities. Kennedy and Cohn describe a program that was successful in including hearing-impaired students in a German classroom. The students learned to lip read and to pronounce German words, although they could not hear the teacher, other students or themselves. Reading and writing were challenging, but the students were able to achieve success in these areas as well. Through close collaboration with administrators, special education specialists, students and parents, 
German teachers can participate in mainstreaming: "The academic performance of the five hearing-impaired students supports the finding of conducted surveys that academic performance of mainstreamed students is superior to their non-mainstreamed counterparts" (164-5). Although significant effort was required to bring about this success, "[i]t was a very proud moment for the German teacher when, during a vocabulary game, one of the most difficult to understand hearing-impaired students stood up and pronounced the word correctly" (165).

Suggestions that teachers should incorporate awareness of diversity in their teaching has engendered controversy. Many who display resistance to the perspectives of multiculturalism and similar synthesis or integration on the basis of gender, sexual orientation, physical or mental disability, etc., are not necessarily rejecting the goal of reducing discrimination but may be rejecting the excesses of some proponents of political correctness. As Peters explains: "It is to be feared that well-meant efforts to promote true educational diversity have come to be greeted by lethargy, skepticism, or even cynicism as the result of an indiscriminate use of the term." Teachers must endeavor to maintain a proper perspective on diversity: "Progress in equality made by women, ethnic minorities, gays and lesbians, handicappers, and other minority groups seems threatened by a surprisingly virulent backlash, guised at time[s] in the mantel of 'family values' respectability." As editor of Die Unterrichtspraxis, Peters introduces an issue devoted to diversity with an exhortation for teachers to "consider the word 'diverse' afresh, in the untarnished meaning with which it was first used to characterize 
what will be, without doubt, the make-up of our classrooms . . in the twenty-first century" (vii).

\section{New Perspectives}

Fourth, German teachers must consider new perspectives in the teaching of culture. These can and should include a combination of theories about culture, cultural learning, and cultural instruction; and perspectives on proficiency. The complex working definition of culture illustrated above through teachers' attitudes toward culture finds parallels in professional literature on cultural instruction:

Although culture contains knowable facts, these facts are in constant flux. More important ... is an appreciation of culture as a constellation of phenomena in a continual process of change, brought about by the participants in the culture as they live and work. Culture is in the process of becoming and should therefore be taught as process. (Crawford-Lange and Lange 142)

To do this, teachers should select activities which enable students to arrive at a view of culture as a process. A hands-on learning style is appropriate to this objective.

The inseparability of culture and language is an important theme in the field of sociolinguistics:

Cultures tend to exhibit differences in the perception of what are relevant or acceptable topics of conversation as well as who can address 
whom under what circumstances. Effective use of a language . . . is based on culture presuppositions about the kinds of language behavior that are appropriate for particular situations and the expectations people have regarding effective structuring of information. (Olshtain 50)

Therefore, teachers must present language and culture together, as integrated components rather than separate topics. Students must understand that words contain implications of a larger world view: an American's conception of a house includes familiar styles of architecture, an understanding of who is likely to live there, and their lifestyle; in contrast, a German's conception of a Haus includes different styles of architecture, a different understanding of who is likely to live there, and their lifestyle. Likewise, an American may feel embarrassed and admit to it; a German would feel embarrassed but not acknowledge it. The selection of which words to use, if any, is connected to the larger world view of the given culture.

Such characteristic differences give rise to stereotypes: studies document the stereotypes Americans hold of Germans, associations which include beer, wine, the Wall, both World Wars, Nazis and concentration camps (Webber 135). With associations such as these, German teachers face the challenge of educating their students not only on the breadth of 2,000 years of German history and culture, but on seeking deeper meanings behind frequent stereotypes. Webber discusses the way in which stereotypical thinking operates. "[M]eaning is created as the viewer reacts to, and interacts with, particular aspects of the object in the light of attitudes, abilities, and 
experiences which the viewer brings to the object" (132). A study of self is necessary when studying another culture. The definition of ethnocentrism above establishes that ethnocentric thinking, where present, inherently casts the other culture in a negative light. Webber suggests three ways teachers can approach stereotypes in the classroom. In "perpetuation," the teacher does not respond to a stereotype when a student expresses one. This allows the stereotype to continue. In "repression," the teacher suppresses information for any of several reasons, which may include inappropriateness of the information for the student based on the student's own culture. In "critical confrontation," the teacher acknowledges the stereotype and uses it "to explore both the reasons (personal, sociocultural, and cognitive) why the image has been constructed as it has; and the extent to which the categorization is valid." This allows the student to gain insight into the structure of the stereotype, its function in the student's culture, and "the processes of forming judgments in general" (137). Stereotypes can unlock culture as process.

Proficiency principles are well-suited to an integrated presentation of German language and culture. The proficiency method is not a method but an organizing principle which offers a wealth of insight that teachers can apply in making decisions about methodology (James 3). Its foundation is the functional trisection of function, content and accuracy (Higgs 4). Function is the communication task the student will attempt in the foreign language, such as negotiating plans for the weekend or telling what he or she did last weekend. Content is the specific information which the student 
must convey or understand. This includes vocabulary and knowledge of the people, their lives, and culture. Accuracy is the student's ability to make him- or herself understood, including both pronunciation and use and accuracy of grammatical forms (Omaggio, Methodology 331). Students learn the foreign language curriculum in each of these areas to three levels of mastery: conceptual control, partial control, and full control (Heilenman and Kaplan 63-6). Using a spiral syllabus in which material repeats for mastery and expansion (Sieloff-Magnan 122-3), teachers can present language content organized around cultural themes (Crawford-Lange and Lange 147).

Proficiency and culture become one:

educators have been emphasizing the need to incorporate a cultural syllabus into the curriculum and to promote global awareness and crosscultural understanding. The use of techniques to increase this type of understanding should receive a high priority in proficiency-oriented classroom instruction. Such techniques might include the use of culture capsules, culture clusters, culture assimilators, minidramas, audiomotor units, realistic survival situations, and the simulations of cultural events. (Omaggio, Classroom 80)

Since "a proficiency-based curriculum specifies outcomes in terms that relate to realworld language functions" (Heilenman and Kaplan 59), the value of proficiency as a guiding principle in the teaching of culture is certain. 
Culture, or content in the functional trisection, can become the driving force in proficiency-based curriculum design, with function and accuracy adjusted to keep step. While culture should serve as the highest-level organizer, it can only function as an overarching theme or topic for a given unit: the focus must be on "what students can do with a language, not what they know about it" (Bellman 37). Hence, teachers must decide on a cultural theme, then ask themselves what performance tasks students should engage in that relate to the theme. Arries discusses three tools which form a basic blueprint for constructing culture-based units. First, teachers should ask their students what cultural topics they are interested in learning. Once a topic is established, teachers can invite native speakers to serve as culture informants. Students can prepare themselves to ask questions about the cultural topic. Finally, teachers can use audiomotor activities to further practice and refine both language and cultural knowledge (524-6). The value of culture as a thematic organizer, relevant to student interests and needs, is clear. The use of performance tasks in constructing the blueprint for activities is consistent with the proficiency-based classroom.

Crawford-Lange and Lange propose a process for teaching language and culture consisting of eight stages. This process meets the authors' strict standards for language and culture instruction: it requires the teaching of culture alongside language; it integrates language and culture; it allows for variation in the abilities of the students; it provides affective and cognitive objectives; it acknowledges culture's ever-changing nature; it enables students to alter their views of culture; it enables students to interact 
in the target language, demonstrating cultural awareness; it teaches that members of a culture have an impact on the shaping of the culture in which they live; it relates the target culture to the students' native culture; it places the students in active roles as learners in a student-centered classroom (146).

The eight stages Crawford-Lange and Lange propose are:

Stage 1: Identification of a cultural theme.

Stage 2: Presentation of cultural phenomena.

Stage 3: Dialogue (target/native cultures).

Stage 4: Transition to language learning.

Stage 5: Language learning.

Stage 6: Verification of perceptions (target/native culture).

Stage 7: Cultural awareness.

Stage 8: Evaluation of language and cultural proficiency. (147-50)

In identifying cultural themes, Crawford-Lange and Lange distinguish between topics and themes. They cite employment as a topic, but "employment for adolescents in a depressed area" as a possible theme. The strength of this example as a theme is its tighter focus and closeness to students' lives. Any theme must include the notion of universality (147). Presenting the culture is possible through "bulletin board displays, slides, overhead transparencies, films and filmstrips, videotape ... and written text." These materials provide examples of the cultural theme in real life. As the dialogue on culture begins, students describe, analyze and react to the target culture. Students 
should write about their perceptions. As the students commence learning the language associated with the cultural theme, the previous dialogue can serve as a source of inspiration. Students have encountered the target culture and responded to it. Now, they will explore it further, coming closer to it through the target language. Vocabulary and grammar are presented as relevant to the study of a real culture. This includes appropriate use of language in cultural situations (148). In the next stage, students practice the language features and vocabulary which they know are needed to speak about and participate in the target culture (148-9). The knowledge gained through direct experience with the language and culture can now serve as a tool to empower students to approach the target culture directly. Students should now have greater access to authentic materials. They can research and explore in keeping with personal interests. "This stage is the second dialogic opportunity for students" and "may incorporate increased use of the target language" as the students now have the language skills with which to discuss and participate in the target culture. Projects are appropriate during this stage. In the next stage, students develop a synthesis of the knowledge gained through language study and deeper investigation (the "second dialogic opportunity"). They determine whether their earlier perceptions based on first exposure to cultural phenomena were valid. They try to account for any changes in their perceptions which may have occurred as they learned more about the target culture. This stage develops and refines critical thinking skills which are applicable to other subjects and experiences throughout life (149). In the final stage, the teacher 
evaluates the students' progress, determining how proficient they have become in handling the target language and culture. Students can demonstrate this progress through additional projects in which they share their new knowledge (150).

Two observations regarding the culture presentation process merit attention. First, teachers must decide in which language to present cultural information. Some teachers prefer to speak only the target language in the classroom; others make at least some use of the students' own language in order to clarify directions and present information for which the students lack sufficient linguistic ability in the target language. Flewelling suggests that it is acceptable to use English when teaching German culture to American students if the value of the information outweighs concerns about language use. Hence, teachers can present more engaging units on culture to beginning students, who will learn to use the target language appropriate to their level of proficiency. There is an obvious advantage in making the curriculum intellectually interesting and challenging even at lower proficiency levels. Also, high schools which emphasize teaching across the curriculum will find it appropriate to provide incidental use of written English even in a foreign language classroom.

Nonetheless, "there is no pat answer" and teachers must make this decision on an individual basis. In either case, "[s]tudents should always be made to see the link between language and culture" (136).

The second observation concerns whether students should first consider their own culture before examining the foreign culture, in order to identify their own beliefs 
before they impose them on another culture. This has obvious advantages in heightening student awareness of issues that may relate to stereotypes that will emerge in the study of the target culture. However, no clear consensus on the importance of this is evident in the literature.

Finally, in considering perspectives on the teaching of culture, teachers should be aware of opportunities for content-based instruction in the foreign language classroom. Moeller indicates that interdisciplinary units reflect a fundamental difference between middle school and high school instructional models. Middle schools make extensive use of them; high schools and colleges do not (536). "Content-based instruction arose from the need in foreign language and English as a Second Language (ESL) immersion programs to teach the standard curriculum while focusing on instruction in a second language." In the foreign language classroom, students would be "immersed in the foreign language while learning the content of the other areas. The fundamental organization of the curriculum is derived from the subject matter" instead of grammar. The curriculum may be presented through lectures or hands-on activities. The strength of this approach is that it "provides many more contexts for communication than if language were taught in isolation" (537). Benefits of contentbased foreign language instruction can include "enhanced motivation, self-confidence, second language proficiency, and cultural literacy" (538). Moeller relates this to the themes around which teachers construct units. Instead of a cultural focus on French cities, or a more focused theme such as adolescents living in large cities which may be 
relevant in an urban school setting, Moeller would suggest a unit that considers where France's larger cities are located. "The students then analyze the location of these cities, hypothesize why," and compare this to the locations of large American cities and possible reasons why they occur as they do (540). Culture can serve as a bridge in interdisciplinary units.

\section{New and Traditional Resources}

Fifth, teachers must consider ways to utilize new and traditional resources in their teaching of culture. Historically, the major resource teachers drew from in teaching culture was literature, an artifact of Big C culture (Flewelling 133). As Little C culture gained favor beginning in the 1960 s, non-literary cultural artifacts found a place in the foreign language classroom. Martin and Laurie add an important dimension: students' own perspectives toward language learning, culture and literature. Their 1991 study lends weight to what have previously been only impressions that teachers develop based on their interpretation of student attitudes. Any foreign language teacher should recognize the consistency between Martin and Laurie's findings and his or her own classroom observations.

Martin and Laurie find that the primary reason most students study a foreign language is to speak it (188). Hence, development ofthe four skill areas is of paramount importance to students. With this emphasis, students are more likely to find cultural study to be directly relevant to language skill development. Students do not 
commonly view literature as essential to an understanding of culture or as helpful to the development of reading, writing, listening and speaking skills as a direct study of culture. In fact, a study of Little C culture was generally of more interest to students than a study of Big C literature. Nonetheless, a study of literature was still of interest to most students $(195,199)$. There was a marked difference between two groups of students, which Martin and Laurie call "pro-literature" and "anti-literature" students. The former viewed literature more favorably in general. The latter were students taking only introductory courses in a foreign language. Their majors were in other departments, often departments "which do not normally include subjects of a literary or discursive nature: economics, science or linguistics programs." A major obstacle to both groups was the feeling that they lacked preparation: "unfamiliarity with the historical and cultural context of literary works seemed to be a recurrent theme". All students also feared literature taken out of context or presented without connections to their own experiences (201).

In spite of their expressed reluctance to study literature, and their belief that culture was more helpful to language skill development, all students did recognize that literature could also play a role in language skill development. Literature could provide vocabulary, place language in context, and serve as a basis for conversation. However, students did not feel that literature would be helpful to "such pragmatic goals as travel or employment." Only if a tourist wished to stay for an extended period in the target culture would a study of literature likely be helpful. Additionally, only careers in 
"teaching or perhaps diplomacy" would make use of knowledge gained through a study of literature (Martin and Laurie 202). Students' emphasis on development of the four skill areas and cultural knowledge over literature was definite.

This does not suggest that literature is not suitable or desirable in the foreign language classroom. Stewart and Talburt take a much more optimistic view. They affirm that literature continues to carry at least some interest for all students and all students are able to recognize that literature can convey cultural insights and aid in the development of language skills $(48,49)$. Nonetheless, they acknowledge a decline in enrollments in literature courses (46). Stewart and Talburt cite four factors which may be to blame: incompatibility with objectives (students want to learn productive language skills and do not view literature as the best way to achieve this), the curriculum (emphasis on Big C texts when most students are interested in Little C culture), pedagogy (students do not enjoy the teaching methods commonly employed to teach literature), and lack of preparation (students feel they lack sufficient background knowledge to interpret foreign language texts, including cultural and historical knowledge). Teachers must also take into account differences in individual learners when attempting to find solutions (46). Interestingly, Stewart and Talburt "find no evidence to support suggestions that a lack of cultural knowledge is an impediment to understanding literature" (50).

At stake is how teachers view literature: how teachers organize, integrate and present literature in the foreign language classroom: 
As a rule, the teaching of reading and the teaching of culture occur independently in many foreign language classrooms. However, using authentic texts to stimulate cultural insights as well as to teach reading strategies is one means of accomplishing these goals simultaneously. (Alvarez Evans and González 40)

Teachers should organize cultural units around themes found in literature. Rather than presenting Goethe or Schiller because they are part of the German literary canon, German teachers can make their lessons more relevant and engaging by presenting works or excerpts of works by these or other German authors connected to topics, themes or issues which affect the students' lives. Alvarez Evans and González describe a pilot study which focused on Spanish literature that reflected Hispanic attitudes toward family. They present a variety of prereading, reading and postreading activities by which students can learn about this aspect of Hispanic culture, relate it to their native culture, and learn the Spanish language in the process (40-7). Careful use of prereading activities and an emphasis on "highlighting familiar and guessable words" enabled students to make progress toward a fuller understanding of the text in question. Students were able to overcome obstacles that might otherwise have deterred them from attempting to read literature. Activities such as "think-alouds" and "guessing and predicting" were especially helpful, as well as having students verbalize "their own values" while effecting a comparison of native and target cultures. Clearly, literature study can be effective in the foreign language classroom when integrated with 
culture study and language skill development. It should not drive the curriculum in the way it, and grammar, once did. Instead, cultural themes can serve as the centerpiece, with synthesized language skill/culture study preparing students for yet another application of their knowledge: the reading of authentic texts.

Teachers should consider a variety of both literary and non-literary texts. The need for teachers to address the diversity of their students (Henderson, Action 4) raises the question of whether teachers should include works of German literature in the curriculum which deal with German diversity. Although common stereotypes of Germany portray that country as exclusively Aryan, there are in fact a growing number of non-whites living in Germany. For example, "currently ca. 200,000 persons of African descent (African and/or African-American and German heritage) are German nationals". Africa and Africans "have captured the literary and artistic imagination of the German-speaking world at least since the Middle Ages" (Hopkins 121). Inclusion of German texts dealing with or written by Africans is not a misrepresentation of the diversity of the German historical or cultural experience.

Grimm relates an historical perspective on two African saints. Saint Maurice was depicted as white "although he, a black African Christian, had suffered martyrdom as the leader of a Roman legion originally stationed in and recruited from Africa." Maurice was revered in what is now modern France and western Switzerland. Otto I introduced the cult of Maurice to Germans who honored him "only from mid-tenth century onwards". A sculpture of the saint, clearly depicting a black man in medieval 
European war mantle, was constructed at the Magdeburg Cathedral around 1240 (127). Grimm also relates the story of the three Magi who attended Christ's birth. The youngest of the three, Balthasar, "was white when first depicted but was transformed into a black saint in Germany during the Middle Ages." Albrecht Dürer's Adoration of the Magi, completed in 1504, depicts Balthasar, also called Caspar, as "a handsome young black African and a splendidly clad and adorned prince." While there is no suggestion that a study of either Maurice or Balthasar should replace Goethe in the curriculum, there is no valid reason for restricting the study of German literature only to Goethe and others in the traditional canon. At the least, students will likely respond positively when a teacher takes the initiative to make curriculum relevant to them and their interests.

Dietrick explores this possibility in her article, German Literature and Generation $X$. Teachers must not forget "the essential foreigoness of German texts for our students". Indeed, "reading lists should reflect our own teaching aims rather than a canon rooted in the culture of German-speaking Europe" (1). Teachers can no longer assume that students will recognize the value or importance of the traditional curriculum (2). Dietrick states that educators today face the job of teaching a new generation of students:

Born in the '60s and '70s, they grew up, and grew up quickly, in the middle of a social revolution launched by their elders. Particularly when it comes to their intellectual attainments, Generation $\mathrm{X}$ has received 
very poor reviews .... [They] have an encyclopedic knowledge of old sitcoms, commercials and pop music . . but [not] history and the great thinkers of civilization; their interests and goals are shallow, without moral vision, and materialistic. (2)

Dietrick identifies four factors which have correlated with this generational change. First, curriculum in general has shifted focus from content-emphasis to skills emphasis, and from "teacher-centered to learner-centered". Second, "demographic reality and a lingering recession have frozen much of Generation X out of jobs and wealth now monopolized by their elders." Third, greater diversity is now the social norm. Dietrick finds Generation X "more at ease with their elders, more open to negotiation about differing points of view" than she recalls the previous generation which attended college in the 1960s and 1970s. Fourth, books must today compete with other media: "Print culture and the sustained modes of thought that it supports must now compete with that barrage of disconnected information ... which characterizes the electronic age" (3).

In spite of the differences between this generation and those which preceded it, Dietrick stresses that literature contains universals which continue to speak to all generations:

... Gutenberg and Luther, at the beginning of another revolution in information technology; Lessing in the struggle of rational inquiry with religious fundamentalism; Goethe at the birth of modern individualism; 
Günderrode reflecting on nature, society and gender; Kafka with his visions of anonymous bureaucracy; or Christa Wolf's meditations on living inside a culture directed by power elites. (4)

The question is not whether the traditional canon should be taught, but how it should be taught. If teachers present literature on a thematic basis, as one more artifact of culture, and connect it to the students' own culture(s), students are more likely to identify with it. Careful use of prereading, reading and postreading activities can strengthen student confidence. Lastly, literature should not consist exclusively of Big $\mathrm{C}$ literature, but include Little $\mathrm{C}$ materials. The key is to make literature meaningful to today's students:

As the keepers of writing, narrative and cultural memory, what we have to offer is not a service, but a gift. One does not apologize when one offers someone a gift. But these days, the big question is whether the people we are offering it to even recognize it as a gift. (Dietrick 6) One approach to the inclusion of Little $\mathrm{C}$ texts that may appeal to teachers uncertain about their place in the curriculum is to emphasize the roll non-literary literature can play in encouraging intermediate students to read extensively in the foreign language. Jürgen Koppensteiner recommends the Jugendbücher of Christine Nöstlinger and other Austrian writers, since "Österreicher in der deutschsprachigen Jugendbuch-Szene eine führende Rolle spielen" (106). 
In the case of Nöstlinger's novels aimed at adolescent readers, Koppensteiner finds many positive attributes about the writing as well as the effect the novels had on third-year college students who read them. Most of Nöstlinger's novels are realistic stories about everyday people, including students, parents and extended family, teachers, and workers; and everyday situations. There is much in these novels with which young readers can identify. Koppensteiner quotes Nöstlinger: “"Meine Leser haben ... Interesse an Vätern, Müttern, Tanten, Lehrern, Schularbeiten, Fahrrädern, Liebe, Spielplätzen, Taschengeld und Autos"' (107). These things are not "spezifisch Österreichisches" but are understandable to American students as well. In her other novels "bedient sich Nöstlinger einer Art von "phantastischem Realismus"” (108). Although fantastic, these stories avoid the "“Wegträum-Phantasie"" common in traditional children's literature: "Das Phantastische weist immer auf eine Utopie vom Besseren hin" Nöstlinger has a clear purpose for her use of the fantastic: "Das Phantastische und Skurrile wird in der Geschichte als ein Mittel eingesetzt, um zu mehr Toleranz und zu einer humanitären Einstellung aufzurufen. ..." Other qualities of Nöstlinger's novels include "Humor, Sprachwitz, Unbekümmertheit und ein gehöriger Schuß Situationskomik" as well as the author's intercession in favor of tolerance and against "Vorurteile, Inhumanität und Krieg" (108).

Of particular interest is Nöstlinger's novel, Maikäfer flieg!, an autobiographical novel about the end of World War II in Vienna (108-9). The protagonist, an eightyear-old girl similarly named Christine, befriends a Russian soldier who takes her to her 
grandparents' house, which has been bombed. As a result, the soldier later faces charges of desertion. Koppensteiner finds many important social lessons for young people in this story:

Der ganze Roman wird von einer Weltsicht der Humanität und des Friedens getragen, die Sinnlosigkeit des Krieges wird drastisch vor Augen geführt. Vor allem aber zeigt die Autorin, daß auch in einer Zeit des Chaos, des Horrors, menschliche Wärme vorhanden sein können, ja müssen. Als die eigentlichen 'Helden' erweisen sich die Schwachen und die Stillen. (109)

The power of the novel lies in its ability to speak to young people of today, who will identify with the protagonist and, following the little girl's adventures, allow themselves to risk caring about the enemy. The novel amplifies the relevance of past events, the universality of the human experience, as it speaks against tyranny (110).

Although Maikäfer flieg! is not of the same literary caliber as other works in the traditional canon, in part due to its intended audience of young people, the fact that students can access it at an intermediate reading level and see it as a book to read for enjoyment will encourage them to attempt it. Using a series of such Jugendbücher, which students can read from cover to cover, will build confidence and foster a positive attitude toward reading in a foreign language, while offering many important cultural lessons (Koppensteiner 109). Such novels can serve to open the door to the traditional canon. Perhaps they can provide the much-needed middle step to soften the jarring 
transition between lower-division language and upper-division literature courses. At the very least, Little $C$ texts can be an engaging, non-threatening way to present culture through reading, even at the high school level.

In the proficiency-oriented classroom, German teachers must reach beyond literature and non-literary texts to the inclusion of other authentic written materials, or realia. Alice C. Omaggio formulates a working set of hypotheses which form the basis of the proficiency approach. Her first hypothesis states that students must have opportunities to learn the language "in a range of contexts likely to be encountered in the target culture" (Methodology 332). The fourth corollary to this hypothesis states that:

A proficiency-oriented approach emphasizes the use of authentic language instructional materials wherever possible. The contexts for language practice should be ... from culturally authentic sources. The use of real or simulated travel documents, hotel registration forms, biographical data sheets, train and plane schedules, authentic restaurant menus, labels, signs, newspapers, and magazines will acquaint the students more directly with real language than will any set of contrived classroom materials used alone. (Omaggio, Methodology 333)

Such materials are of great advantage in the lower levels of a proficiency-oriented curriculum where students are building basic language skills. Students at higher levels, 
traditionally exposed only to $\mathrm{Big} \mathrm{C}$ culture, can also benefit from exposure to a variety of authentic sources.

\section{In Zeitgeschehen und Zeitkritik im DaF-Unterricht, Maren Partenheimer}

observes that lower- and mid-level texts are typically driven toward grammar instruction. Beyond this, teachers may present “"Überlebensdeutsch und Smalltalk” centered on topics like dining, money, requesting a hotel room, the family, etc.; and cultural and geographical information as facts. The prevalence of such modular patterns of presentation in many textbooks evidences the need for authors of course materials to work toward a more integrated approach toward teaching language skills and culture, and toward a view of culture as process. Partenheimer points out that no textbook can present current events, only general information that will presumably remain valid while the book is being published, distributed, sold and adopted for use. Hence, it is the responsibility of the instructor to include current happenings in the course curriculum, as they arise (qtd. in Partenheimer 29).

Partenheimer cites frequent objections to the use of current events sources, including a busy schedule driven by the need to complete the textbook in so many months, the urgency of preparing students for upcoming tests which place current events in a distant second place, teachers feeling they are out of touch with the daily happenings in the German-speaking countries as they are "überarbeitet ... und zuviel Hefte korregieren [müssen]," and students do not know enough German to engage in meaningful discussion of current events. Although these objections are well-founded, 
there is no justification for not including important, current cultural information in the curriculum. Most students only take two years of a foreign language: it is not possible to wait. Hence, teachers must make the effort to include current events within existing constrictions (30).

Partenheimer offers a systematic method for accomplishing this. Unfortunately, this method calls for the segregation of language skill and cultural learning. Partenheimer is not against using English in part at the lower levels in order to build student interest and enthusiasm. The valuable content outweighs language concerns, if briefly. Beginning the second semester, the target language is more feasible as the primary language for cultural instruction. Approaching written news reports and videotapes of news programs with an eye to those words the students can recognize, the teacher can direct students toward gaining an appreciation for which events are of current interest in the German-speaking countries, and possibly arrive at some consensus on how Germans seem to feel about them (30). Although Partenheimer does not seem particularly well-acquainted with proficiency principles, the approach is essentially the same as that which would occur in the proficiency classroom. Partenheimer offers several suggestions for discussion topics, with vocabulary and questions for reflection. Students at an intermediate level would be able to perform these activities with allowances (31). Whether at the novice level or above, at least some relevant and insightful use of current events is indeed possible. Teachers can aid 
their students by matching activities to the students' level of mastery and by making partial use of the students' native language as needed at the lower levels.

Numerous articles speak to the issue of using authentic video or film in the classroom. Gislind E. Pentecost of Ball State University recommends the video series Deutschlandspiegel. Each monthly episode is about fifteen minutes long, containing "aktuelle und auch zeitlose Informationen" concerning many areas of life in Germany, from country to city life, cultural topics, German history, politics and society, education, the media, sports and holidays. An English series is also available. As of 1992, Deutschlandspiegel appears semi-annually, each $16 \mathrm{~mm}$ film print or video version containing six monthly episodes. Printed materials useful to teachers accompany the series. All materials may be copied without charge when used for instructional purposes (196-7). Pentecost provides examples of how teachers may use the videos in class. One suggestion is to play the video without sound, and ask the students questions about what they have seen. The advantage here is that beginning students will not be intimidated by fluent German and teachers can target the discussion directly to the class in question in terms of vocabulary, structures, and topics of interest. With preparation, even beginning students can listen for specific information, from words to phrases, details to general impressions (198).

For more advanced students, an in-depth research project concerning German film is a possibility. Hyde L. Flippo describes his experiences with cinema projects prompted by the death of Marlene Dietrich in 1992. His high school students' 
awareness of and interest in this sad event led him to conceive of a unit focusing on the contributions of German cinema (132). In the beginning, his purpose was primarily to motivate the students. Successive projects were able to refine and hone research and presentation skills. Students chose a topic from a list and conducted research outside the classroom. Flippo required them to use at least three sources, one of them in German. The reports were 3-5 pages in length. Success was varied:

One of the better reports, done in German by an advanced student, drew parallels between Fritz Lang's Metropolis and modern science fiction films like Blade Runner, RoboCop, and Star Wars and pointed out how these modern films were influenced by and directly reflected Lang's 1927 original. (Flippo 134)

Flippo mentions "an actual worst-case scenario" to demonstrate the kinds of problems that may arise with such film projects. A report on Arnold Schwarzenegger's films became a five-minute video presentation of violence and profanity without adequate analysis or comment until Flippo stopped the tape and indicated that greater creativity was necessary in the way the student interpreted the material (134).

Flippo recommends that teachers considering such film projects first acquaint themselves with resources that are readily available in their communities, as students will need to access resources outside of class. Teachers must also provide "specific examples" of the reports and presentations that students are to create. Teachers must allow "adequate time" for students to complete their work, including the setting of 
"[i]nterim deadlines". Teachers must help students in "narrowing the focus of the report." Finally, Flippo recommends that teachers and students alike allow themselves to appreciate their involvement with the project. Films are interesting and enjoyable and a unit focusing on them should be similarly entertaining (135). Using cultural themes found in films as the center point, teachers can enhance the value of such projects in teaching culture.

Russell G. Rose provides detailed information about the use of satellite television in the teaching of French. He stresses that satellite television "offers foreign language teachers what few other resources can: it provides a continuous source of up-to-date, authentic language and culture materials." Programs include "news programs, talk shows, documentaries, variety shows, dramatic series, cooking shows, cartoons, and feature films. . . ." Schools may obtain the programs directly through their own satellite dish systems, or purchase programs through services which make them available to educational institutions, such as the Satellite Communications for Learning Association (519). Teachers find many ways to use authentic video materials, but Rose emphasizes three essential steps that any plan should include: "prepare students for what's to come, have them engage in a variety of activities, and evaluate them on what they learn" (523). The technology and its implementation may seem expensive, time-consuming or complex, but Rose believes the "benefits of satellite television ... far outweigh the problems. Few instructional materials are as dynamic as 
satellite television, and few are as effective in showing students the reality of the language they are studying" (518).

Mary E. Wildner-Bassett discusses the use of television commercials in the foreign language classroom as a vehicle for culture. She distinguishes four areas of cultural instruction that television commercials may address. The first is convention, or the use of "routinized expression" or "communicative routines". For example, "Guten Tag!" as a formulaic greeting (55). The second is connotation: "the point at which language and culture come together to form meaning ... it deals with developing the learners' inferencing skills at several levels. ..." These skills require students to interpret speech acts in the broader context of situations, with awareness of cultural attributes. The third is conditioning, which involves insight into the foreign cultural system in order to understand that individuals behave "in a manner consistent with the structure of their own culturally conditioned systems or frames of reference." Hence, students must seek the Weltanschauung of the target culture and learn to place actions and events within a cultural frame of reference (56). The fourth area is comprehension, which "includes such skills as analysis, hypothesis formation, and tolerance of ambiguity." Although full functioning in this area of cultural understanding requires Superior skills on the ACTFL scale, "the gradual acquisition of these skills can begin at the novice level" (56-7). Wildner-Bassett suggests these questions for discussion at either the secondary or post-secondary level: 
1) What is the product being advertised? 2) What are the qualities of that product? 3) Can you list 3-5 expressions used by the people to indicate their approval of the product? 4) Who uses what expressions?

5) What are the differences in the people and in the expressions? 6) Could a figure like this appear in an American commercial? Why or why not? 7) Based on what you have seen on American television from ... [Germany], would you expect to meet a person dressed like this on an average street in Germany today? 8) Are there any equivalent commercial character types in American television commercials? 9) Does this tell us more about the television audiences in the U.S. or in the Federal Republic, or does it merely tell us something about the advertising techniques? (56)

The fast pace and immediate situation-recognition aspects of television commercials make them ideally suited for use in the foreign language classroom. Their "highcontext communication" value make them very desirable as tools in the teaching of culture (54).

Teachers can maximize control over their use of visuals when they develop their own slide collections. Video (except laser-disc) requires distracting effort at cueing, fast-forwarding and rewinding: slides may be sorted and arranged as needed for individual lessons, drawing from a larger collection. Advancing through them is usually easier than pausing and recueing videotape. Although there is some cost associated 
with building a personal slide collection, the reusability and recombinability of slides give them lasting value. Outdated slides can be contrasted with more recent images to spark conversation on the changes occurring over time in the country where the target language is spoken. Teachers can augment commercial slide collections with their own slides, made during trips abroad or from photographing printed materials and other artifacts (Myers 75). One ready source of images can be the local community: a foreign language teacher can make slides of the local city hall, post office, etc., and use this as a counterpart to images of a German Rathaus, Postamt, etc. Slides of featured locations can be projected as a backdrop when students practice speaking in realistic situations. Myers stresses their appeal to visual and auditory learners which should make slides—and class discussion of them—an integral part of any foreign language course (78).

Slides of not only artwork and architecture, but also documents, historical figures and places, as well as points of geography and geology, typical shots of life both urban and rural often open up in-class discussion to students somewhat reluctant to enter into more bookoriented material. (Myers 75)

Slides drawn from a personal collection can greatly enrich the presentation of cultural content in foreign language courses and interdisciplinary courses as well (Myers 78).

Stressing the appeal of Little C culture to students, Bernd Conrad addresses the use of popular music in foreign language instruction. A University of Texas study 
which asked students to identify their course preferences based on "medium and content" found that $21.3 \%$ of respondents were interested in a course on popular music, $19.4 \%$ in a course on Grimms' fairy tales, $18.5 \%$ in a film course, $8.6 \%$ in a course on "authentic texts" which the students themselves chose, and $8 \%$ in a "standard" foreign language course. Conrad interprets this to signify that students "prefer courses in which they are familiar with the medium of presentation (film, popular music), for which they have previous knowledge of the content (fairy tales), or in which they select readings based on their own interests and backgrounds (authentic texts)" (18-9). While Conrad does recognize that some teachers will question of the value of popular music as an instructional resource, he feels that popular music's "potential for cultural comparison and identification" justify its inclusion in the curriculum. Music, Conrad states, "promotes emotional and rational allegiance to ... culture." The fact that German students listen to and identify with popular music in much the same way as their American counterparts provides a point of similarity on which German teachers can capitalize to lead their American students closer to an appreciation of the target culture. Music "builds an effective and affective motivational framework" (20). Conrad quotes the Goethe Institute, which believes that dieses Medium [Rockmusik] besondere Vorteile für den fremdsprachlichen Unterricht bietet, well es beim Hörer Emotionales, Nichtsprachliches anspricht. Es erlaubt, wie kein anderes Medium, den 
Schüler, mit seiner Sensibilität, mit seiner Erfahrung, seinen kreativen Fähigkeiten in den Unterricht einzubeziehen. . . . (20)

Conrad provides seven categories for popular music, which provide a framework for teachers designing cultural units that may include popular music:

1. Geschichte der deutschen Rockmusik

2. Amerikaner aus deutscher, Deutsche aus amerikanischer Sicht

3. Nachkriegsgeschichte und Vergangenheitsbewältigung

4. Zwischenmenschliche Beziehungen

5. Außenseiter und Arbeitslose

6. Reisegewohnheiten der Deutschen

7. Umwelt und Lebensbedingungen. (20)

These categories suggest a tighter focus to cultural topics and a strong relevance to American students, which are essential ingredients in the development of cultural themes as the basis of cultural units (see page 25).

Use of technology in the classroom increasingly means use of computers and Computer-Assisted Language Learning (CALL). Michael Schwartz describes the troubles with integrating technology into foreign language instruction. The problems reach back to the introduction with language laboratories in the 1950s and 1960s: in spite of their promise, studies found "no discernible effect on student achievement" when students used language laboratories. There has been a consistent mismatching of materials and methods with ways in which students actually can or do learn. Materials 
developers must focus not on features that could prove helpful, but on features that students use in practice. Compatibility of methods between what teachers do in the classroom and what students will do with the technology is essential (527). Today, researchers seek a broader understanding of the role that computers can play in foreign language education. They raise questions about what skills or knowledge computers can help students achieve, especially in areas outside simple grammar or vocabulary drills; at what levels and in what contexts computers are useful; which students benefit most from use of computers; which computer programs are most useful at developing which skills; the effect of computer use on affective learning; and peripheral effects of computer use, such as impact on school attendance (527-8). Computers can also prove a valuable source of data on how students learn, as student work and progress can be recorded and monitored over time. The research is just beginning even as computer technology continues its rapid evolution (532). Schwartz urges adequate teacher training as necessary if any successes are to occur (534).

Studies such as that by Nagata and Swisher, A Study of Consciousness-Raising by Computer: The Effect of Metalinguistic Feedback on Second Language Learning, serve as an open invitation to classroom teachers to follow up with their own action research projects. This study contrasted "traditional computer feedback that indicates only missing or unexpected words in the learner's response" with a new style of "intelligent computer feedback that provides further information about the nature of the errors in the form of metalinguistic rules." Students receiving more in-depth feedback 
showed greater progress (337). Classroom teachers could experiment with this and other variables as they seek efficient and productive ways to utilize computer technology in the classroom.

With access to the Internet, computers can now become powerful purveyors of authentic cultural materials. "Approximately 30 million people have full access to the Internet" (Olive and Pollastrini 551). This number increases daily. The Internet offers an enormous wealth of information of all kinds. While the quality of individual sites varies, teachers can access government agencies, national newspapers, research institutions, cultural and civic groups, tourist information, maps, geographic and climate information, historical sites, even multi-media sites with streaming video and audio, including film, television and popular music materials.

Oliva and Pollastrini describe a study they conducted using e-mail, newsgroups, and Internet Relay Chat (IRC), as well as a popular word-processing program in a target-language version. These tools and "other more traditional teaching tools" allowed the instructors to use "a whole-language approach to the teaching of Italian" (553). The instructors designed their project to make use of "Krashen's Monitor Model/Theory" with the principle that "[a]cquired language competence is a subconscious process promoted by situations involving a high degree of communicative urgency." The Internet was useful in creating that urgency or need to communicate, particularly e-mail which allows the instantaneous transfer of written communication. The structure of the project corresponded to three trends in foreign language 
pedagogy: "more authentic communication in the classroom ... content-based instruction ... and learner-centered education" (552). The study found that students appreciated learning computer skills which might be useful to them in the future. They enjoyed the freedom of communicating by e-mail, which does "not require physical presence in the same place at the same time for communication to occur." The researchers observed a "positive impact on student learning" and found that "writing skills are most affected by Internet-Mediated Instruction (IMI)." In addition, many students "noted that the immediate application of lessons helped them to listen and read better and to retain new vocabulary more effectively" (557). The opportunity to access target culture Internet sites and interact through e-mail or chat with native speakers, who can serve as culture informants, make the Internet an outstanding tool for the teaching of culture.

Finally, teachers must consider study abroad, work abroad, and other direct and personal contacts with the target culture as indispensable resources in the teaching of culture. King and Young of Oregon State University relate the findings of two surveys which sought an understanding of student "prejudices, desires and opinions about study abroad." They found that most students had heard of study abroad opportunities available through their university (77). $7 \%$ of all students expressed plans to study abroad, another third of all students were not sure of their plans. Only $2 \%$ of all students reported having already taken part in a study abroad program (78). A majority of students ( $66 \%$ female, $73 \%$ male) reported having traveled abroad. Of 
those who had traveled abroad, about half had traveled alone, $26-24 \%$ had traveled with a group, and only $4-9 \%$ had experience as an exchange student. The primary reason for not studying abroad was cost $(68 \%)$, followed by the need to become proficient in a foreign language (34\%) disinterest (23\%), concern about immersion in a foreign culture (18\%), leaving a close friend $(18 \%)$, and leaving their parents $(12 \%)$ (79). Gender differences in reasons for not going abroad included females more likely not to want to leave a close friend ( $25 \%$ female to $17 \%$ male), their parents $(19 \%$ female to $9 \%$ male), and more likely to express concern about cost ( $82 \%$ female to $75 \%$ male). Conversely, more males expressed concern at the need to become proficient in a foreign language ( $40 \%$ male to $36 \%$ female) and disinterest ( $32 \%$ male to $17 \%$ female) (80).

This study also revealed that students who have prior study abroad experience are more likely to have majors in the liberal arts, business, agriculture and education. Students with majors in forestry, science, engineering or pharmacy, or whose majors were undecided, were less likely to have prior study abroad experiences (80). The most alluring reason to engage in study abroad was the opportunity to earn an international degree, which consists of a regular BA or BS degree plus 32 credit hours in international studies, including language proficiency equal to four years of university study (77\%). The next most appealing reason was the opportunity for an internship in a foreign company (43\%). Obviously, students want to be able to see practical gains for their time and money if they are to engage in study abroad programs (80-1). 
Nonetheless, the number one personal reason for going abroad was "[e]nriching personal life" (100\%), followed by "[b]roadening perspective on own culture" (97\%) and "[e]nhancing undergrad[uate] educational exper[ience]" (92\%). Other reasons trailed behind in comparison: "[d]efining or changing occupational goals (55\%), "[s]uccess in present job" (42\%), "[a]dvancing career" (41\%), "finding first job" (31\%), “[f]urthering graduate education" (27\%) (82).

The cultural benefits of living in a foreign country are obvious. Immersion in the target culture allows the student to experience a vast array of cultural input, to use all four language skills in the acquiring of cultural knowledge, to encounter the greatest quantity and variety of authentic materials. If teachers seek to understand the reasons students have for going abroad, and the fears that might keep them at home; then teachers will be in a position to advocate for study, work and travel abroad experiences. Cultural instruction in the foreign language classroom must function as a bridge for those students who will ultimately find themselves living in the target culture. It must also serve as an important lesson in tolerance to the many other students who will only spend one, two or three years in a foreign language classroom and never travel abroad. In either case, the role of culture in the foreign language classroom must be significant, intimately tied to the teaching of language skills. 


\section{CONCLUSIONS}

Two final dimensions require attention before, and as, conclusions are drawn about what German teachers should think, believe, and attempt to do as teachers of culture. Ultimately, both of these dimensions relate directly to the teachers themselves.

First, teachers must seek to understand the larger context in which they will work as foreign language teachers. Much is already clear: America is changing demographically. The classrooms of today and the coming decades will surely present teachers with increasingly diverse students, all of whom are important, all of whom require a meaningful, personalized educational experience if they are to succeed. Teachers must teach to new and rising standards in student-centered classrooms where hands-on learning and the development and demonstration of proficiency are the norm. Foreign language teachers must remain abreast of new developments in their field, drawing from new perspectives as they teach integrated culture/language skills, viewing culture as a process, not a set of facts. Teachers must also learn about new technologies, and ways of using new and traditional resources. Teachers must be risktakers, willing to try new ways, new materials if they are to meet these challenges. 
It is not surprising that the AATG, in this era of rapid change, has begun work on a plan for national standards for German teachers. The AATG views this approach as "essential for meeting the educational demands of the $21^{\text {st }}$ century" (Schultz et al. 81). Since the AATG serves as the national organization representing all German teachers, from primary through post-secondary, they are highly connected both to the profession and the professionals in it. The AATG believes that the growing diversity within the U.S. and growing interdependence between nations justify inclusion of foreign languages alongside English as core subjects in the next century:

In order to function in that enlarged and ever-changing environment, students need to be able to reason and think critically and creatively. Language facility is a crucial tool for attaining these goals. Our students must be able to reflect on the many uses of language in order to grasp their meaning and significance. They must also be competent to participate in the diverse discourses that mark human interaction within and between social, cultural, and linguistic groups. Only then will they be able to reach their potential as citizens of this country and the global community. (Schultz et al. 82)

National standards would bring with them national certification. Teachers who meet the new standards would receive AATG certification which "provides evidence of superior teaching ability and performance" and "demonstrates a high level of professionalism". Similarly, districts would interpret certification as verification that 
teachers have the necessary language skills, subject knowledge and training as teachers. Certification would also play a role in compensation (Schultz et al. 83). The proposed standards would focus on five areas:

1. commitment to student learning;

2. knowledge of subject matter and pedagogy;

3. responsibility for managing and assessing student learning;

4. reflection and flexibility; and

5. commitment to life-long learning. (Schultz et al. 84)

For each area there are specific guidelines. In demonstrating their commitment to creating success for every student, including recognition of and teaching to different learning styles, German teachers would:

create classroom environments that reflect the cultures of the total student population;

develop and use materials/lessons that reflect the diversity of learners; develop ... a an articulated curriculum of sequential study; coordinate German instruction with the total school curriculum ...; participate actively in the development of interdisciplinary lessons or programs. ... (Schultz et al. 84)

In meeting the second standard on subject knowledge and language skills, teachers would pass a test and allow observation and evaluation of their teaching. They would also actively participate in school and community activities and 
opportunities for travel and study abroad in order to remain current in their knowledge of the target culture (Schultz et al. 85-6).

In meeting the third standard, which calls for professional competence concerning pedagogical issues, teachers would:

clarify learning expectations and help students take responsibility for their learning;

organize instruction so that it is learner-centered, by addressing students' interests, needs, abilities, developmental levels, and learning styles;

adapt and/or create instructional materials that are appropriate, relevant, and current;

provide activities and materials that foster critical and creative thinking; use technology to deliver or support instruction, student feedback, and assessment;

provide frequent and unambiguous feedback ...; [use] a range of performance-based assessment procedures; know how current instruction relates to an articulated curriculum sequence ... and design instruction accordingly. (Schultz et al. 89)

Teachers would meet the fourth and fifth standards, which call for professional reflection and continuing education, through research, such as action research projects aimed at improving their own performance; preparing articles for publication; reading 
professional journals; interacting with other teachers as mentors and peer-reviewers; involvement in school and community events and organizations; participating in or conducting workshops; and developing new courses, including interdisciplinary courses (Schultz et al. 90).

These efforts at raising standards for teachers complement national and state goals of raising standards of student achievement. The profession may or may not decide to adopt these standards or adhere to them in the future, but their formulation has already prompted teachers to reflect on the role of their profession in the next century.

Second, teachers must ask themselves who they are as teachers of culture. They must seek a deeper understanding of their individual role in the often mysterious learning process by which their students develop knowledge and skills related to the foreign language and the target culture. They must seek to grasp their limits, their strengths and weaknesses:

I worry that students will ask me how to say something I don't know in the target language....

Sometimes I scrap plans to do a particular activity because I worry that I will make too many mistakes.

I feel uncomfortable speaking my target language in front of other language teachers. 
I feel uncomfortable speaking my target language to native speakers of the language. (Horwitz 365)

A significant number of foreign language teachers in the U.S. are native speakers of English. They may feel uncomfortable performing before a room full of students who may ask any question about the target language or culture at any time. Anyone who has ever attempted it knows that the process of learning a foreign language never arrives at an endpoint. It is a lifelong event. Beyond concerns about language skills, teachers may ask themselves how they can represent another culture when, in all likelihood, their own personal contact with that culture has been limited. It is a perplexing and uncomfortable situation, highly ambiguous, yet one that talented individuals choose to make into a career (Horwitz 365-6). Interestingly, native speakers can also find the prospect of serving as a representative of their own culture a daunting and uncertain proposition. They must ask themselves what image or aspect of their own culture they feel truly qualified to teach (Bammer 1).

Essential to both of these dimensions is the role of teacher training in preparing teachers for the classroom. Although teacher training programs seek to prepare individual teachers, they perform this function within the context of larger trends within the profession and education in general. Tedick and Walker cite these problems in teacher training:

1) a failure to consider the interdependence between first and second languages and cultures; 
2) the fragmentation and isolation of language arts fields;

3) the pervasive view of language as 'object';

4) a paralyzing focus on methodology, and

5) a continued failure to link language and culture... (500)

Tedick and Walker call for closer cooperation between college and university programs which prepare German teachers and the schools in which these individuals will teach. Those who provide training must work together to mentor student teachers (513). A critical piece in this collaboration must be reflection. Mentors must observe the results of their work: the successes and failures of those they train. Mentors must reflect on the environment in which their student teachers operate and, ultimately, seek employment. Student teachers must learn early the value of critical self-reflection and action research (513-4).

Such reflection, on the personal level and the relatively impersonal level of the profession at large, is essential if teachers are to successfully adapt to the challenges they face now and in coming decades. The traditional paradigm is no longer valid in today's world, or in working with today's students. Generation X, which now fills German classrooms throughout the country, is a diverse and intense generation with its unique needs. Foremost among them may be the need for recognition. As their name implies, these students are individuals in search of identity. More varied than any 
previous generation in American history, they demand an education which is not blind to them, but which understands them, embraces them, speaks to them in terms they can understand. It is the job of today's-and tomorrow's--German teachers to make the German language and German culture relevant, interesting, exciting. The key which will make this possible is culture.

Students want more than anything to speak the language. They are not averse to learning the literature and elements of $\mathrm{Big} \mathrm{C}$ culture, but they are primarily interested in the German people and wish to seek them out through a variety of Little $\mathrm{C}$ artifacts. The time has come to remove grammar and literature from their historical position of prominence and replace them with culture. Teachers must present language and culture as one. By organizing units around cultural themes, German teachers can give their work focus and relevance. Teachers can teach language skills and provide exposure to literature, cultural materials, and other realia, within the context of these cultural themes. Teachers can broaden the canon to reflect the diversity of their students and succeed in making the curriculum, as a bridge to the traditional canon, more meaningful and appealing. This is not selling out, but keeping up. The alternative is to be left behind.

Eric G. Underwood quoted these words from the 1917 Report of the Prime Minister's Committee on Modern Languages in Volume 1, Number 1 (October, 1919) of the British journal, Modern Languages: 
'We are, and must be, concerned with modern studies as an instrument of culture; and by culture we mean that training which tends to develop the higher faculties, the imagination, the sense of beauty, and the intellectual comprehension. Clearer vision, mental harmony, a just sense of proportion, higher illumination-these are the gifts that culture ought to bring. ...' (241)

Through new perspectives on teaching language and culture, and the use of new technologies and new and traditional resources, German teachers can teach their students to rising standards and achieve the goals which have long been their desire. 


\section{WORKS CITED}

Alvarez Evans, Gilda, and Olgalucía G. González. "Reading 'Inside' the Lines: An Adventure in Developing Cultural Understanding." FLA 26 (1993): 39-48. Arries, Jonathan F. "Constructing Culture Study Units: A Blueprint and Practical Tools." FLA 27 (1994): 523-34.

Ballman, Terry L. "Integrating Vocabulary, Grammar, and Culture: A Model FiveDay Communicative Lesson Plan.” FLA 29 (1996): 37-44.

Bammer, Angelika. "Critical Performances.” UP 25 (1992): 1-9.

Cadd, Marc. "An Attempt to Reduce Ethnocentrism in the Foreign Language Classroom.” FLA 27 (1994): 143-60.

Conley, David T., et al. Proficiency-Based Admission Standards Project. Oregon State System of Higher Education. Initial Draft. Prepared for OSSHE Review Panel. November 18. 1993. Eugene Oregon. Office of the Vice-Chancellor for Academic Affairs. Eugene: Oregon State System of Higher Education, 1993.

Conrad, Bernd. "Contemporary and Historical Contexts in Popular Music: Theory and Implementation of an Intermediate Level Course." UP 24 (1991): 18-30. 
Crawford-Lange, Linda M. and Dale L. Lange. "Doing the Unthinkable in the Second Language Classroom: A Process for the Integration of Language and Culture." Teaching for Proficiency: The Organizing Principle. Ed. Theodore V. Higgs. Lincolnwood, Illinois: National Textbook Company, 1984. 139-178.

Dietrick, Linda. "German Literature and Generation X." UP 27 (1994): 1-6. Fischer, Gerhard. "Tourist or Explorer? Reflection in the Foreign Language Classroom." FLA 29 (1996): 73-81.

Flewelling, Janet L. "The Teaching of Culture: Guidelines from the National Core French Study of Canada." FLA 27 (1994): 133-42.

Flippo, Hyde L. "Marlene Dietrich in the German Classroom: A German Film Project -Humanities and Language through German Cinema." UP 26 (1993): 132-9.

Grimm, Reinhold. "Two African Saints in Medieval Germany." UP 25 (1992): 12733.

Grittner, Frank M. "Editor's Introduction to This Special Edition on Culture." FLA 29 (1996): 17-8.

Heilenman, Laura K., and Isabelle M. Kaplan. "Proficiency in Practice: The Foreign Language Curriculum." Foreign Language Proficiency in the Classroom and Beyond. Ed. Charles J. James. Lincolnwood, Illinois: National Textbook Company, 1985. 55-78.

Henderson, Ingeborg. “Addressing Diversity: A Call for Action." UP 24 (1991): 4-9. 
.. . "Preparing for Diversity: From Administrative Planning to TA Trainng." UP 25 (1992): 107-15.

Higgs, Theodore V. Introduction. "Language Teaching and the Quest for the Holy Grail." Teaching for Proficiency: The Organizing Principle. Ed. Theodore V. Higgs. Lincolnwood, Illinois: National Textbook Company, 1984. 1-10. Hoopes, David S., and Margaret D. Pusch. "Definition of Terms." Multicultural Education: A Cross-Cultural Training Approach. Ed., Margaret D. Pusch. Yarmouth, Maine: Intercultural Press, 1979. 2-8.

Hopkins, Leroy T. "Expanding the Canon: Afro-German Studies." UP 25 (1992): 121-6.

Horwitz, Elaine K. “Even Teachers Get the Blues: Recognizing and Alleviating Language Teachers' Feelings of Foreign Language Anxiety.” FLA 29 (1996): $365-72$.

International Monetary Fund. World Economic Outlook: October 1996. A Survey by the Staff of the International Monetary Fund. Washington, DC: International Monetary Fund, 1996.

James, Charles J. Introduction. "Learning from Proficiency: The Unifying Principle." Foreign Language Proficiency in the Classroom and Beyond. Ed. Charles J. James. Lincolnwood, Illinois: National Textbook Company, 1985. 1-8. Kennedy, Zita M., and Eva R. Cohn. "Mainstreaming Hearing-Impaired Students into a Foreign Language Class.” UP 25 (1992) 164-5. 
King, Lynda J., and John A. Young. "Study Abroad: Education for the $21^{\text {st }}$ Century." UP 27 (1994): 77-87.

Koppensteiner, Jürgen. "Das schriftstellernde Phänomen in der deutschsprachigen Jugendbuch-Szene: Ein Plädoyer für die Arbeit mit Texten von Christine Nöstlinger.” UP 23 (1990): 106-11.

Liskin-Gasparro, Judith E. “The ACTFL Proficiency Guidelines: A Historical Perspective." Teaching for Proficiency: The Organizing Principle. Ed. Theodore V. Higgs. Lincolnwood, Illinois: National Textbook Company, 1984. 11-42.

Martin, Anne L., and Ian Laurie. "Student Views About the Contribution of Literary and Cultural Content to Language Learning at Intermediate Level." FLA 26 (1993): 188-207.

Minert, Roger P. "Factors Influencing Enrollment in Public High School German Courses: Results of a National Survey." UP 25 (1992): 173-83.

Moeller, Aleidine J. "Content-Based Foreign Language Instruction In the Middle School: An Experiential Learning Approach.” FLA 27 (1994): 535-544. Myers, Michael. Tools for the Classroom. "Production and Use of Slides for Language and Culture Classes." UP 26 (1993): 75-9.

Nagata, Noriko, and M. Virginia Swisher. "A Study of Consciousness-Raising by Computer: The Effect of Metalinguistic Feedback on Second Language Learning." FLA 28 (1995): 338-47. 
Nollendorfs, Valters. "Out of Germanistik: Thoughts on the Shape of Things to Come." UP 27 (1994): 1-10.

Oliva, Maruizio, and Yvette Pollastrini. "Internet Resources and Second Language Acquisition: An Evaluation of Virtual Immersion." FLA 28 (1995): 551-63. Olshtain, Elite. "Language in Society." Research in Language Learning. Principles Processes and Prospects. Ed. Alice Omaggio Hadley. Lincolnwood, Illinois: National Textbook Company, 1993. 47-65.

Omaggio, Alice C. "Methodology in Transition: The New Focus on Proficiency." MLJ 67 (1983): 330-340.

- - . "The Proficiency-Oriented Classroom." Teaching for Proficiency: The Organizing Principle. Ed. Theodore V. Higgs. Lincolnwood, Illinois: National Textbook Company, 1984. 43-83.

O’Mahony, J. Patrick. "Promoting German among Students of Color: A Report on the Student Task Force on Diversity at UC Davis." UP 25 (1992): 116-20. Oregon State. Cong. House. Oregon Educational Act. By Vera Katz, et al. $66^{\text {th }}$ Oregon Legislative Assembly. 1991 Reg. Sess. HR 3565. Salem: State of Oregon, 1991.

Oregon State Department of Education. Adopted Common Curriculum Goals. Content \& Performance Standards (\& Current Scoring Guides). October, 1996. Salem: Oregon Department of Education, 1996. 
Otto, Karl F., Jr. "Minorities and Materials." UP 25 (1992): 153-7.

Panetta, Leon E. "The Quiet Crisis of Global Competence." UP 24 (1991): 127-31.

Partenheimer, Maren. "Zeitgeschehen und Zeitkritik im DaF-Unterricht." UP 25 (1993): 29-32.

Pentecost, Gislind E. “Das Deutschlandspiegelvideo.” UP 26 (1993): 196-9.

Peters, George F. Editor's Corner. UP 25 (1992): vii-viii.

Peters, George F., et al. "Report and Recommendations of the AATG Committee for the Recruitment and Retention of Minorities in German." UP 26 (1993): 97-8.

Rose, Russell G. "French-Language Satellite TV in the Classroom." FLA 28 (1995): $518-26$.

Ryan, Phyllis M. "Sociolinguistic Goals for Foreign Language Teaching and Teachers' Metaphorical Images of Culture.” FLA 29 (1996): 571-86.

Schultz, Renate A., et al. Special AATG Reports. "Professional Standards for Teachers of German: Recommendations of the AATG Task Force on Professional Standards.” UP 26 (1993): 80-96.

Schwartz, Michael. "Computers and the Language Laboratory: Learning from History." FLA 28 (1995): 527-35.

Sieloff-Magnan, Sally. "From Achievement toward Proficiency through MultiSequence Evaluation." Foreign Language Proficiency in the Classroom and Beyond. Ed. Charles J. James. Lincolnwood, Illinois: National Textbook Company, 1985. 117-45. 
Stewart, Melissa A., and Susan Talburt. "The Interplay of the Personal and the Pragmatic: Language, Culture, and Interpretation in the Spanish Literature Classroom." FLA 29 (1996): 45-55.

Underwood, Eric G. "The Road Before Us." ML 70 (1989): 241-3.

Webber, Mark. J. "Intercultural Stereotypes and the Teaching of German." UP 23 (1990): $132-41$.

Wildner-Bassett, Mary E. "A Video Visit to the Land of Them: Commercials and Culture in the Classroom." UP 23 (1990): 54-60. 